\title{
BIOMASS LOCAL PRODUCTION SYSTEMS AND THEIR MANAGING - ALTERNATIVE TO RURAL DEVELOPMENT IN SLOVAKIA ${ }^{1}$
}

\begin{abstract}
Local production systems (LPS) focused on biomass usage represent a viable alternative to rural development, which can contribute to solve its socio-economic problems in Slovakia. The main objective of this paper was to propose a general framework for the functioning of biomass LPS in rural areas and to summarize the main points for smooth running of biomass LPS projects aimed at the resource base, method of obtaining energy from biomass, energy production cycle and a dialogue with inhabitants of municipalities where biomass LPS are to be located. Lack of experience in implementing such projects was the root cause of problems in Banská Bystrica region. Therefore, access to information, experiences form other countries and the development of appropriate formal and informal linkages are necessary for knowledge transfer and play an important role in managing biomass LPS.

Keywords: local production system, biomass, rural development, project management.
\end{abstract}

\section{INTRODUCTION}

Energy demand in many countries is growing rapidly and energy is considered as a cross-cutting issue that contributes to the achievement of all the Millennium Development Goals. Decisions taken in the energy sector at the national level in the coming years (Bolcárová, Kološta 2015: 704) will have long-term consequences for investment, the society and the global climate. Access to energy is as fundamental to human welfare as clean water, agricultural productivity, health care, education, job creation, and environmental sustainability. Energy supply should be sustainable and free from the drawbacks of conventional energy sources such as harmful emissions, noise, high fuel costs and supply insecurities. The call for sustainable access to energy for development purposes is further underlined by

* Matej Bel University in Banská Bystrica, Faculty of Economics, Department of Public Economics and Regional Development.

** Matej Bel University in Banská Bystrica, Faculty of Economics, Department of Public Economics and Regional Development.

${ }^{1}$ This paper was prepared as one of the outputs of the $7^{\text {th }}$ Framework Programme FP7-PEOPLE-2011 IRSES Project No. 295050 FOLPSEC - Functioning of the local production systems in the conditions of economic crisis (comparative analysis and benchmarking for the EU and beyond). 
declaring the decade 2014-2024 as the Decade of Sustainable Energy for All by the United Nations General Assembly (Terrapon-Pfaff et al. 2014: 2).

Every nation must tend to use energy sources, apply energy policies and take care of energy-related environmental aspects in order to achieve developmental targets (de Arce et al. 2012: 335). As a result of the increase in global population and economic growth, energy consumption has considerably increased worldwide, from the equivalent of 6,630 million tons of oil in the early 1980s to 11,295 million tons in 2008 (Ruhl 2008: 3).

Energy policy is a strategy employed by governments to address issues such as energy generation, distribution and consumption, as well as their environmental and social impacts. Countries must select from different policies to find the mix, which would be the most appropriate for their targets, technical abilities and culture. Therefore, there is no optimal worldwide method and governments must continually improve and reform energy policies (Mertilot 2012: 5). Rapid increase in the use of renewable energy has been possible through decreasing technology costs, increasing fossil fuel prices, and paying out state subsidies (Abolhosseini, Heshmati 2014: 878). Worldwide about $9 \%$ of all renewable energy comes from biomass and modern renewables increased their share to approximately $10 \%$.

Current energy consumption of biomass amounts to approximately $53 \mathrm{EJ}$ worldwide. Its major part (86\%) is utilized for heating, cooling and cooking as well as for industry, while $10.5 \%$ is used for electricity generation and $3.5 \%$ for biofuels production. Global biomass based electricity capacity of $62 \mathrm{GW}$ has been in place as of 2010. The leading countries in this field are the U.S. with $10.4 \mathrm{GW}$, Brazil with $7.8 \mathrm{GW}$, Germany with $4.9 \mathrm{GW}$, China with $4 \mathrm{GW}$, and India with 3 GW (Mertilot 2012: 21). These technologies still face numerous social, economic and structural challenges and require not only further technological development but also deeper understanding of both the success factors and the barriers to enjoy their widespread dissemination (Terrapon-Pfaff et al. 2014: 2).

Renewable energy technologies such as wind or solar energy are unlikely to provide a large number of permanent jobs when deployed, but new jobs will be created around them. Significant number of construction jobs will be offered in the construction phase of renewable energy installations but they will disappear when the construction is over. Biomass projects may lead to higher long-term levels of job creation in rural areas. Biomass projects are likely to impact the landscape and wildlife. Also, they may impact the tourist sector in areas where it has become an increasingly important part of the local economy. Therefore, it is important to identify public preferences when it comes to the expansion of renewable energy technologies in rural areas, and to understand public awareness of potential harms and benefits of the expansion (Bergman, Colombo, Hanley 2008: 617). We can better understand how to expand renewable energy in rural areas as a way of reducing carbon emission and improving rural living conditions when we study attitudes of rural residents towards renewable energy (Liu, Wang, Mol 2013: 1187). 
In Slovakia there are projects of biomass heating plants financed from applicants' own resources, the European Union structural funds (ERDF) and from the state budget. Functioning of a biomass heating plant implies activities of other entities in the surroundings, therefore it is possible to talk about the development of a biomass local production system (biomass LPS) in the area.

The main motivation for us to deal with this topic was the missing operational framework of a biomass LPS and the lack of information about issues connected with the managing of biomass LPS in Slovak rural areas. It was confirmed in personal interviews conducted during the visits with the management of such biomass LPS in Banská Bystrica region. Therefore, we summarized the key points that can facilitate smooth running of biomass LPS projects focused on the resource base, the method of generating energy from biomass, energy production cycle and the dialogue with residents of municipalities where biomass LPS is going to be located.

In this paper we focus on 3 main areas dealing with renewables in terms of structure: the use of biomass at national and regional/local levels, biomass LPS and certain aspects of managing biomass LPS projects. The paper also explains how to launch and manage a biomass LPS project and discusses the need to conduct a resource base analysis, understand energy production cycle and the need to establish dialogue among all stakeholders. The paper also analyzes technical problems and solutions to them, which affect socio-economic benefits of the project and may be decisive for the approval of local residents for such biomass LPS. Then, the main goal is to draft a general proposal of biomass LPS and consider its impact on rural development.

From methodological point of view, we applied deductive approach along the following lines: renewables in EU - renewables in Slovakia (potential of biomass and its contribution to rural development) - biomass LPS - some issues of managing of biomass LPS projects. Official statistical data from Eurostat and National statistical office of Slovak republic were used.

\section{RENEWABLE ENERGY AND BIOMASS IN THE EU AND SLOVAKIA}

The importance of renewable energy sources (RES) in the EU is still a hot topic. According to the directive on renewables, their share in energy consumption in the EU in 2020 will reach $20 \%{ }^{2}$. By 2020 Slovakia aims to achieve a $14 \%$ share of energy from renewable energy sources in the total energy consumption, which, considering the $20 \%$ share adopted for the EU, can be regarded a modest goal. Among all countries in Europe, the largest share of renewable energy in the total energy consumption is reported for Norway (over 60\%) and Sweden (over 40\%), as demonstrated by the Figure 1 .

\footnotetext{
${ }^{2}$ Directive 2009/28/EC.
} 


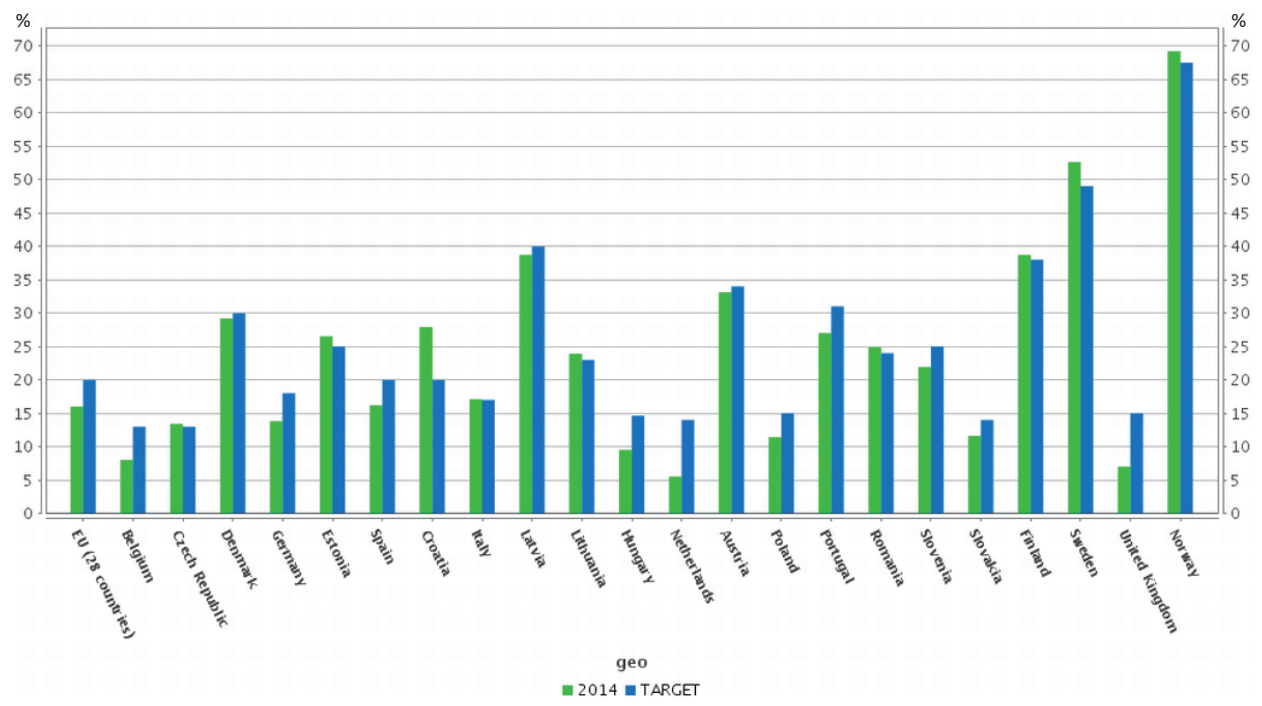

Figure 1. The share of energy from renewable energy sources in total energy consumption in selected countries in Europe

Source: Eurostat.

In Slovakia, biomass represents the largest proportion of technically usable potential of all renewable energy sources $(44 \%)^{3}$. Maga proposed a comprehensive and appropriate definition of biomass, in which he considered biomass an "organic matter of vegetable origin obtained based on photosynthetic conversion of solar energy (phytomass)", but then he continues and adds the understanding of "biomass" as a substance of biological origin, which includes plant biomass grown on land hydroponically in water, animal biomass, organic products and by organic waste" (Maga et al. 2008: 7). According to the purpose, biomass can be used as a heat source, as an energy source for vehicles, as a source of energy for power generation or as a feedstock for the industry, which seems unrelated to energy, but can reduce the amount of energy.

According to Resch, the use of biomass for energy generation in Slovakia will significantly increase by 2020 in both scenarios, NAT (National target fulfilment) and ACT (Proactive support) (Gesch et al. 2010: 23). Calculations show that the use of biomass in Slovakia as the primary energy source will increase from 1.5 to 1.8 Mtoe in 2015 and will vary between 2.0 and 2.5 Mtoe in 2020.

\footnotetext{
${ }^{3}$ Akčný plán využívania biomasy na roky 2008-2013.
} 
To achieve these goals, it is necessary to develop appropriate legislative and administrative framework for the production of energy crops because Slovakia has got big potential in forest and agricultural biomass.

According to the NAT scenario, each EU Member State tries to achieve its renewable energy targets. Exceptions apply to cases when a Member State does not have enough resources or renewable energy would incur costs much higher than the EU average. Countries that are able to achieve its 2020 targets at relatively low costs exceeded its goal and will export energy surpluses to the average level of RES according to the objectives of Europe 2020. ACT scenario portrays an optimistic vision of the RES. Based on the assumption that all EU Member States will actively promote renewable energy (e.g. by introducing a harmonized, but the technology specific feed-in tariffs for electricity from RES support). Moreover, in all cases, it counts in the future with gradual removal of existing non-economic barriers (e.g., administrative bottlenecks, network access, etc.). If the process takes place immediately, it will accelerate spreading renewable energy technologies (Gesch et al. 2010: 10).

In the context of pursuing and monitoring the objectives of the Directive no. 2009/28/EC, national authorities should have "national plan" concerning the development, updating and monitoring biomass use. Finland is a good example in this area (Kautto, Peck 2012: 28).

\section{IMPACT OF BIOMASS USE UPON SOCIO-ECONOMIC RURAL DEVELOPMENT OF SLOVAKIA}

Rural economies can no longer rely on the agricultural sector as a source of employment and wealth growth. Diversification of the rural economy is thus essential to maintain the viability of rural populations (Bergman, Colombo, Hanley 2008: 624).

Biomass, as a form of renewable energy is seen as a source with the greatest potential especially in rural areas. Biomass can be considered an important resource, which could increase product competitiveness in agricultural sector and which contributes synergistically to solve crucial problems in the economy, such as reducing unemployment, rural revitalization, sustainable development and improving the quality of the environment.

Slovakia's landscape is covered in more than $40 \%$ by forests. As shown in table 1, the production of renewable energy from forestry in 2007 was used only at the level of $22 \%$. 
Table 1

Production of renewable energy from forestry in year 2007 and \% from total potential

\begin{tabular}{|c|c|c|c|}
\hline & $\begin{array}{c}\text { Production of } \\
\text { Renewable energy } \\
\text { from forestry (2007) } \\
(\mathrm{KTOE}) 1)\end{array}$ & $\begin{array}{l}\text { Total forest potential } \\
\qquad 20102 \text { ) }\end{array}$ & $\begin{array}{l}\% \text { renewable pro- } \\
\text { duction from total } \\
\text { potential }\end{array}$ \\
\hline Austria & 3930 & 6346 & 6296 \\
\hline Belgium & 649 & 1182 & 5596 \\
\hline Bulgaria & 709 & 1573 & 4596 \\
\hline Cyprus & n.a. & 12 & n.a. \\
\hline Czech Republic & 1948 & 4235 & 4696 \\
\hline Denmark & 1441 & 449 & 32196 \\
\hline Estonia & 731 & 2157 & 3496 \\
\hline Finland & 7149 & 16193 & 4496 \\
\hline France & 9234 & 16494 & 5696 \\
\hline Germany & 10578 & 21051 & 5096 \\
\hline Greece & 1005 & 1266 & 7996 \\
\hline Hungary & 1146 & 1862 & 6296 \\
\hline Ireland & 169 & 652 & 2696 \\
\hline Italy & 1707 & 13853 & 1296 \\
\hline Latvia & 1532 & 3092 & 5096 \\
\hline Lithuania & 732 & 1798 & 4196 \\
\hline Luxembourg & 16 & 224 & 796 \\
\hline Malta & 0 & 0 & 96 \\
\hline Netherlands & 524 & 271 & 19496 \\
\hline Poland & 4550 & 8007 & 5796 \\
\hline Portugal & 2808 & 1843 & 15296 \\
\hline Romania & 3304 & 5940 & 5696 \\
\hline Slovakia & 484 & 2189 & 2296 \\
\hline Slovenia & 429 & 1600 & 2796 \\
\hline Spain & 4206 & 5117 & 8296 \\
\hline Sweden & 8441 & 21816 & 3996 \\
\hline United Kingdom & 784 & 3273 & 2496 \\
\hline Total & 68206 & 142494 & 4896 \\
\hline
\end{tabular}

Source: Elbersten et al. 2012: 52. 
In Slovakia, new technologies in the field of biomass energy create opportunities to use uncultivated or idle land for the cultivation of high-yield crops. It also creates conditions to increase the yield on permanent grassland and little-used mountain meadows and use increased revenues to produce biomass energy (Figure 2). Another possibility is to use brownfields for biomass production. Especially in rural areas, bioenergy can support development, because it exploits biomass, both agricultural and forest.

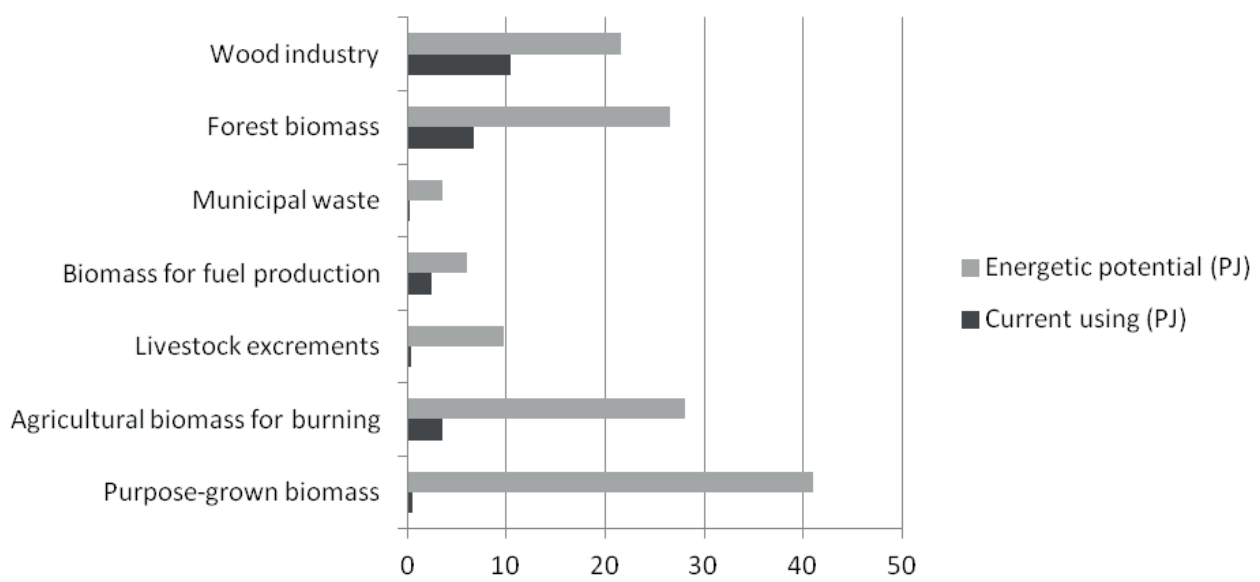

Figure 2. Technical potential of biomass and its use in Slovakia

Source: Biomass Action Plan for 2008-2013, 2008: 12.

Placing bioenergy plants in appropriately selected locations will help create jobs in different areas connected with the industry like planting, management, research and other services. With the advancement of economic growth in a rural region we may expect an inflow of other industrial and service sectors, which previously did not exist or were little present. In this way, bioenergy can become an engine of local and regional economy. It is possible that the establishing of a bio-cluster will encourage innovative behaviour of other entities. Figure 3 summarizes the effects of socio-economic aspects of bioenergy systems for local and regional development.

Social aspects include factors affecting the living standards, social cohesion and stability. Improving of environment is very positive for its protection and conservation, which is an important factor for increasing the quality of people's lives and improve their health. Stable energy base could be also important (e.g. in case of energy crisis). Jobs directly linked to the production and use of biomass can increase employment in other sectors and areas of the economy (direct and indirect employment resulting from bioenergy projects). 


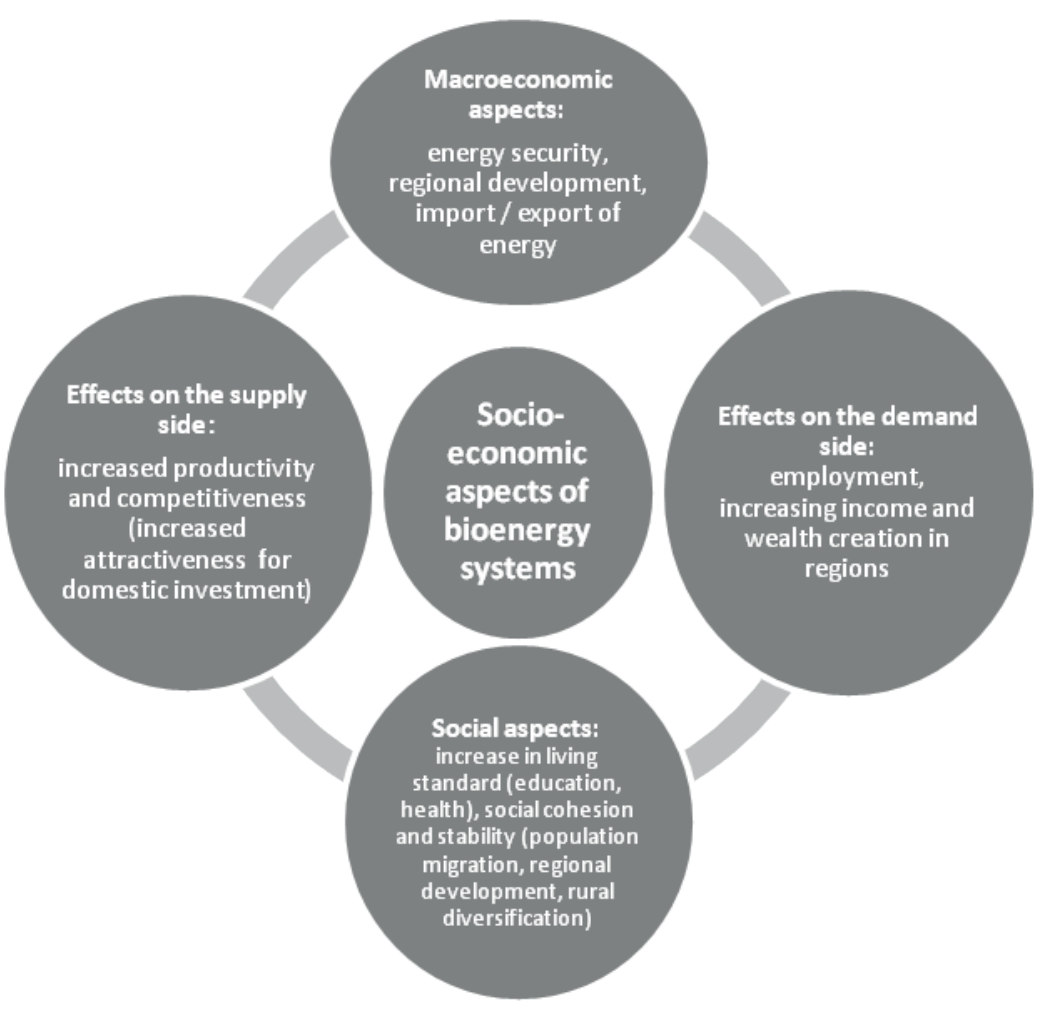

Figure 3. Socio-economic aspects of bioenergy systems for local and regional development

Source: Domac, Richards, Risovic, 2005: 98-100.

Energy exports can stimulate further economic activity in the region. Benefits can be reflected in the improvement of infrastructure but also in reversed migration into areas, from which previously people emigrated (as a result of new job opportunities and better environment than in urban areas). These activities may contribute to the diversification of rural areas and increase the resilience of the rural system. These effects are sustainable if the processes are well organized, which happens in biomass LPS.

\section{PROPOSAL OF A BIOMASS LOCAL PRODUCTION SYSTEM IN RURAL AREAS OF SLOVAKIA}

Local production systems (LPS) are good alternative that can help to solve socio-economic problems especially in rural regions. According to the works of (Crevoisier, Maillat 1991: 13-34; Grotz, Braun 1993: 149-162; Lindkvist 1999: 
16), LPS can be seen as a group of companies located within one geographic region and interactions between them and the environment in which they operate (in terms of economic, social, political, cultural, institutional aspects and infrastructure). Knowledge flows between the entities are important, because the above mentioned physical assets in combination with intellectual abilities produce specific regional characteristics of the LPS. LPS can be also based on the production, processing, transport, and the use of biomass as a renewable energy component (besides the traditional industrial LPS).

Banská Bystrica and Žilina regions have the greatest potential for the use of biomass in Slovakia. These regions recorded the majority of recently approved aid applications for biomass boilers (Figure 4).

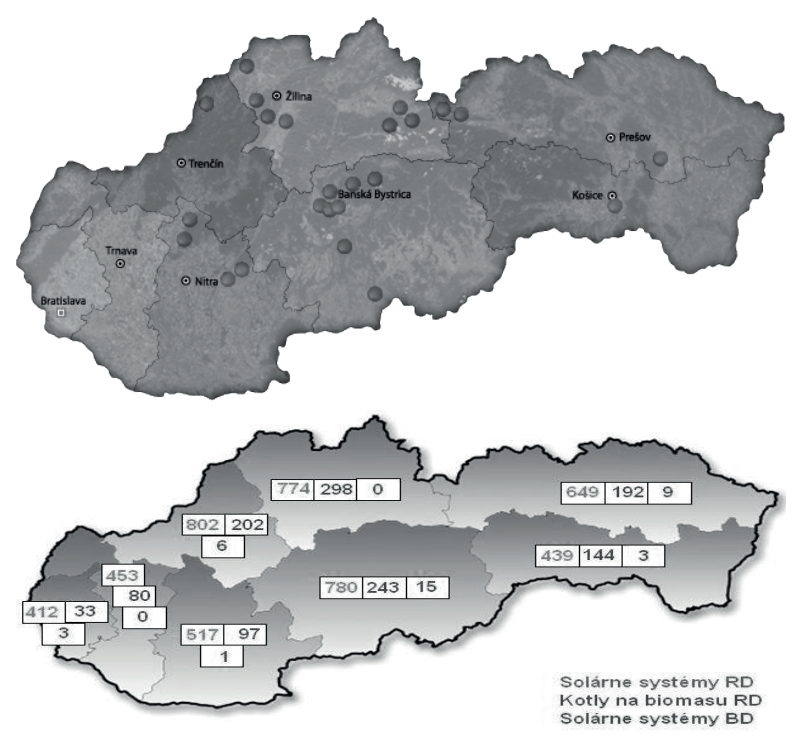

Figure 4. Potential of biomass in Slovakia and the structure of the aid applications by region and type of equipment to be installed - as at 1.09.2011

Left and right - solar systems;

Middle - biomass boilers.

Source: Slovak Innovation and Energy Agency, Atlas of RES.

As an example, we present self-governing region of Banská Bystrica, where there are several entities that have recently received funding from the EU funds for the implementation of new energy solutions using biomass. These include projects in Hrušov, L'ubietová, Detva, Banská Bystrica, Žarnovica and Zvolen.

After consultations with the management directly involved in the implementation of these projects, we found out that these organizations are facing many 
problems related to the lack of information and knowledge about new technologies since the beginning of the investment until putting the installation into operation. Lack of experience in implementing similar projects is also a significant barrier to socio-economic development.

These problems could be mitigated if in the perspective localities there are actors engaged in an operating biomass LPS. Biomass LPS could be also part of regional innovation system aspiring to become a learning region. This would mean that entities directly engaged in production, processing, storage and distribution of biomass - for example heating equipment operators - could be associated within the network of LPS (thus focused either separately or as part of a pre-existing LPS) with:

- consulting institutions (project documentation, financial and technical advice),

- universities and research institutes (e.g. undertaking studies on biomass productivity in specific areas focused on producing of biomass due to altitude and slope of land - as it happened in the Meili mountain in China),

- regional institutions, associations, local and regional authorities, civil society, as illustrated in Figure 5.

\section{Consultancy institutions, universities and research institutes, regional institutions, associations, local and regional governments, civil society}

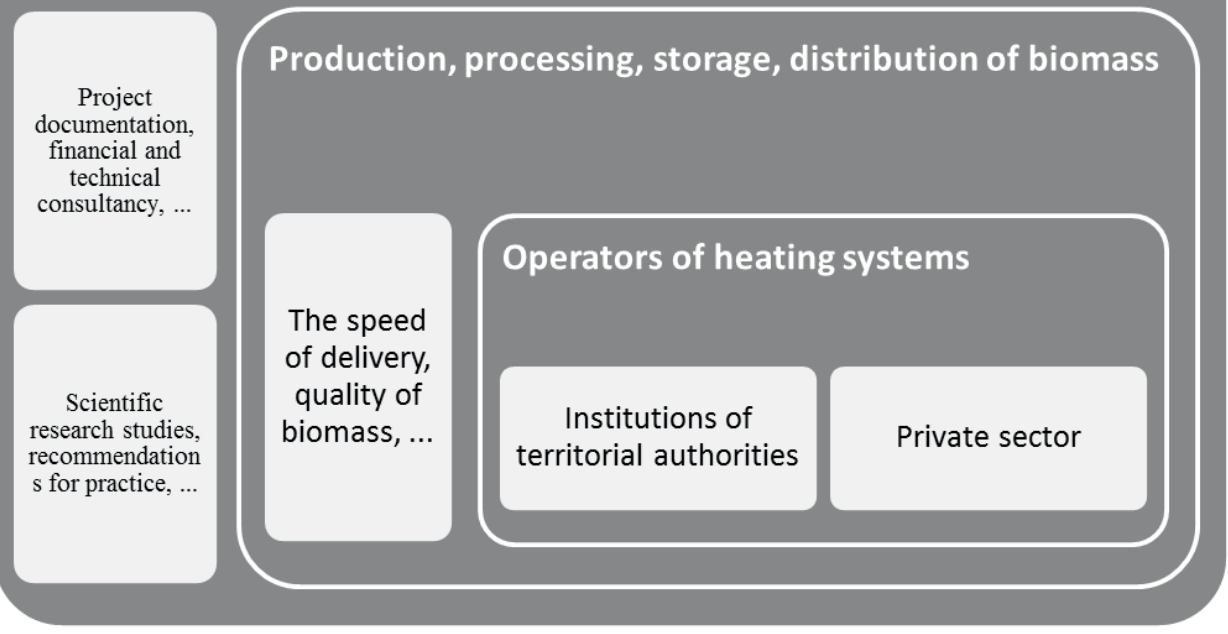

Figure 5. Proposal for local production system focused on biomass

Source: own studies. 
According to our predictions, practical benefits of such biomass LPS consist in better and faster transfer of information between involved actors, effective advice, exchange of experiences, networking, more effective solutions to unforeseen operational problems, streamlining operational processes and in saving transaction costs.

Good example of a biomass LPS that operates in line with our proposal in Slovak rural areas is the association of mountain villages that manage biomass LPS Bioenergia Bystricko. The main idea of the association was to organise a group of villages self-sufficient in energy production and using local wood waste for heating of municipal objects. Instead of buying electric and heating power from private suppliers outside of the micro region they are purchasing energy from village association owned by LPS Bioenergia Bystricko, meaning in a way they pay themselves. Therefore it is a closed circle composed of private businesses, municipal enterprises and municipalities in the administrative area of Banská Bystrica region. These reasons allow us to call it a biomass local production system as illustrated in figure 6 .

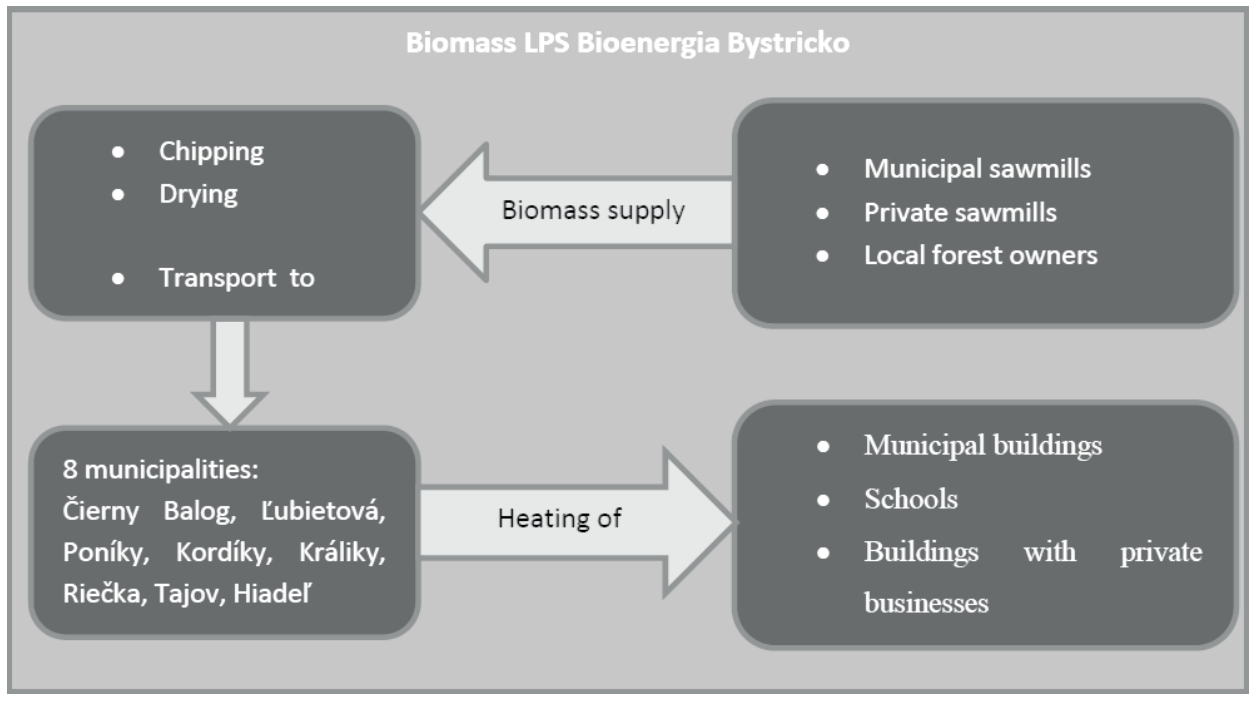

Figure 6. Functioning of biomass LPS Bioenergia Bystricko

Source: own studies.

Heating plants use waste from local sawmills and municipal forest enterprises, thus there is no increase in forest harvest. Municipal or private sawmills in villages and forest owners sell and supply waste wood to the association Bioenergia Bystricko, which grinds raw wood material and stores wood chips in four warehouses where the quality of wood chips is checked. Wood chips 
in storage are usually re-dried for 3-4 months and then distributed according to the requirements and needs of each heating plant to the warehouses located either in reconstructed heating plants or in their vicinity. Municipalities must pay monthly advance payments which are deducted from the final amount calculated at the end of the heating season based on the real consumption of each municipality. Overpayments are paid back. All operating expenses, which cover the purchase of wood waste, chipping and subsequent distribution, storage and costs of the personnel employed by the biomass LPS Bioenergia Bystricko are summed up after each heating season. These costs are then divided among municipalities according to the real consumption of wood chips of each municipality.

None of the 8 aforementioned municipalities was supplied with gas. Before the reconstruction all municipal heating plants provided heat generated mainly from coal. Heating plants were in bad condition, so the organization Friends of the Earth-CEPA offered the municipalities free information service and assistance in the preparation of a project proposal for the reconstruction of all heating plants. Biomass LPS Bioenergia Bystricko rented heating plants from the villages and reconstructed them. This way 15 heating plants were reconstructed and adapted to use biomass. Currently, heating plants supply heat to more facilities than before and that is the effect of the expanded internal and external heat distribution installation and the possibility to regulate heating from additional sources. Besides, 4 independent warehouses for wood chip and fire-wood were built and heating plants purchased technology and equipment, such as a mobile chipper and a transport truck with a trailer, 2 loaders, containers, and a tractor that delivers raw material to the installations.

Project management team is made up of representatives of 8 villages, who are managers in biomass LPS Bioenergia Bystricko. Interviews with managers of the running biomass projects in Detva, Žarnovica, Lubietová provided us with a lot of knowledge, which can be also be useful for managers of a starting biomass LPS.

\section{BIOMASS LPS MANAGEMENT - SELECTED ISSUES}

First of all, a biomass LPS project should be aimed at the analysis of the resource base, method of obtaining energy from biomass and the energy production cycle. Other important elements include mainly: project management, feasibility study, business plan and other technical and economic studies, which we will not discuss in this paper.

When choosing a method of energy production from biomass, it is necessary to analyze the resource base. If we want to achieve local economic, social and environmental benefits at the same time, we should focus on primary raw materials available in the region. The authors of the project must identify: 
- annual demand for biomass,

- its monthly fluctuations,

- the biomass-related logistics aspects, and

- connections to the infrastructure (transport, electricity and heat).

If a biomass LPS is built near a woodworking plant, we can use the wood waste. If demand is sufficient and the operators see the chance to further process waste material (e.g. production of pellets from sawdust), they can acquire raw material base in the nearby area. Imports of biomass from larger distances are not a problem nowadays, but it significantly affects the cost of primary raw materials and does not lead to the reduction of greenhouse gas emissions.

Choosing a suitable technology for energy generation would be largely dependent upon the availability of raw material base in the vicinity. In areas with higher animal production as well as in urban areas where there is shortage of primary raw materials and high potential use of bio-waste in LPS, it is preferable to produce biogas and then install cogeneration units, which combine the generation of electricity and heat. Mountainous areas and areas close to the timber industry should focus on the production of heat from wood products (pellets, chips, briquettes) incinerated in boilers. A similar scenario is possible even in regions with high agricultural production where straw is the main waste material. The decision to combine the production of electricity and heat in a LPS always needs to be preceded with the check of service connectivity to the power line and the cost of technology. Gasification is the appropriate technology in combined heat and electricity production.

We can apply a reverse procedure and adapt the country to our needs of raw materials. It means a change in land use, change in the landscape, excluding the impact on the ecosystem. These aspects may be negatively perceived. On the other hand, adapting the LPS environment to its needs is a more efficient operation (e.g. planting energy crops in the vicinity to reduce the cost of transport), which contributes to lower energy prices and the increased competitiveness in the market. Landscape in the country is also degraded when solar collectors are placed, which happens on not cultivated land, much more difficult to regenerate than after planting energy crops. Visual aspect of biomass crops production is a particular problem when crops are grown on idle land. Similarly, farmed and regularly planted forests do not look like climax forest but still fulfil its functions. Difficulties with the location can be eliminated if we decide to use brownfields and derelict industrial sites (e.g. closed down cement factories, etc.). This does not take up space and new production will remain in the area chosen for that purpose.

After we have selected the mode of biomass-based energy generation, we need to analyse the chain of collection - transport - storage. These factors affect economic and technical characteristics of the project. Subsidy from the EU funds for hardware can cover up to $95 \%$ of eligible costs, but it is a single event. Ensuring quality and affordable materials is an important long-term task. According 
to Sims, transport cost is the most variable part of the cost of primary raw materials (Sims 2002: 45). Integrated biomass collection is an ideal solution. Biomass is often a secondary product, but if you collect it using one machine, you will save costs. The second case is a dedicated biomass collection and conveying in one place. Collection affects the amount of water contained in biomass and thus greatly increases the cost of transport. If the founders of a biomass LPS are not going to produce their own raw material, they should always personally inspect the place from which biomass comes to them.

Transport of biomass plays an important role in energy production cycle. With the intensification of the use of bioenergy, local and possibly regional raw materials may not be enough. That is the case of the bio-cluster in Barnim-Uckermark, where some raw materials are imported by ship (Plieninger, Thiel, Bens, Hüttl 2008: 149-166). Transport may involve hidden cost of the wear and tear of road infrastructure, higher emissions from vehicles, and so on. If taxes in a given territory increased, reactions connected with the use of new energy sources could be very negative. Therefore project authors must always demonstrate the advantages of the new source together with all costs that might arise in the future.

Reducing humidity of primary raw material is an important part of logistics. Water content in the solid mass is different for different types of wood and organic crops and reducing moisture always brings high added value. An optimal solution is to carry out the process at the place where biomass is collected to avoid increased costs of transport. If that is not possible, the problem can be solved similarly as in the Slovak city of Detva where larger roofed storage space allows drying freshly imported biomass. In Hadeland (micro-region in Norway) they are trying to use residual heat in summer months for drying wood chips for future use (Lunnan 2003: 13-16). If in a LPS area plants for biomass production are grown, it implies the need for regular harvest and the depletion of soil nutrients and minerals. To promote sustainability, it is necessary to return nutrients to the soil (e.g. through ash). Each combustion process creates a certain amount of ash which differs from the type of the biomass.

Selling ash to the manufacturers of fertilizers and construction materials seems to be another prospective source of income. At present the use of ash from biomass is very low due to the lack of knowledge, but we can consider it a very promising sector. There are significant development and innovation opportunities opening up also in the agro-sector as a result of using heat for planting.

Another role of the founding fathers of biomass LPS should be to inform and involve all stakeholders (engaged actors) about the project. In this case, national and regional information strategies play an important role. They should present pluses and minuses of technological, economic and social aspects, which will greatly facilitate the work of the initiators. If people are well informed, they can ask questions and avoid unexpected resistance or problems during 
implementation. General information should be provided by the state and regional level (Ministry of Economy, Slovak Innovation and Energy Agency and regional energy centres), while specific features and benefits of the project should be presented by project managers.

The authors of the project should be ready to provide information and answer questions concerning the construction of a biomass LPS (method, time, and technology) for example:

- working hours of companies,

- how and in which way biomass will be transported,

- what is the level of noise produced by traffic and transport,

- what changes should be expected in the landscape,

- the final price for consumers,

- security of energy supply,

- employment opportunities or other economic benefits,

- impacts on the local environment, etc.

It is appropriate that the authors of such a project introduce a simplified model for calculating the price for the end consumer together with a comparison with other options or current energy supply. An average citizen is usually not aware of all costs and legal norms affecting the final price or of the pricing strategy. This way, project creators can avoid possible fast-made decisions as it was the case of, e.g., the project carried out in Slovakia where some users decided to discontinue the distribution of heat from biomass. Information about noise and the time of light pollution (when operating at night) are important not only for the people living in the area but also for local firms, whose employees' productivity can be affected.

Surely, there are questions about the visual aspect of biomass LPS and its impact on the landscape. The initiators should always be ready to visualize the impact of the LPS on the environment. For example in Slovakia, due to underdeveloped road infrastructure, residents often oppose the passage of heavy traffic in the vicinity of their households.

To clarify the supply of biomass and its frequency it is necessary to prevent misunderstandings. The strongest argument (especially due to the current level of unemployment in Slovakia) will be creating or retaining jobs and increasing incomes in the territory and its surroundings, which contribute to better standard of living of the local community.

Many of the above questions could be answered easily if people from the community visited a similar functioning bioenergy installation and see the real situation. Projects using renewable energy sources for a longer time can be found not only in Austria (bio-energetic town Güssing) or Germany (Barnim-Uckermark). Their originators have a lot of experience that can be useful for bioenergy projects and functioning biomass LPS not only in Slovakia. 


\section{CONCLUSION}

Biomass represents an important potential for the development of rural economy and provides an opportunity to recover agricultural activities in specific rural areas. However, large centralized power projects based on biomass can imply potential risks for rural areas, especially in terms of environmental degradation (e.g. by increasing the senseless logging in forests or "cleaning" of forest wood waste after harvest). Therefore it is necessary to select suitable locations for biomass production. This means, biomass energy does not take precedence over the production of quality domestic food.

Local and regional authorities may initiate the establishment of such biomass LPS especially if governments understand the issue of climate change as a local problem and make its solution a strategic priority (Švihlová 2009: 29). We do not see the above proposal of a biomass LPS as a universal model. On the other hand, entities operating in rural areas could draw many benefits from this form of cooperation and coordination of their activities.

Without a systematic approach to biomass and renewable energy in general, it will be difficult to avoid a scenario where financial injections from EU funds into biomass-related technology investments become "an opportunity to produce quick profits". Therefore, the processes of starting and managing of LPS focused on biomass should be well reconsidered.

In Slovakia, the number of projects in the field of bioenergy is growing. Lack of experience in implementing similar projects causes problems in their development and implementation. Therefore, access to learning and the development of appropriate formal and informal linkages are necessary and knowledge transfer plays an important role. Activities of initiators of biomass LPS should systematically focus on strengthening local awareness and cooperation between various entities in order to implement sustainable bioenergy projects as for example biomass LPS Bioenergia Bystricko has done.

\section{REFERENCES}

Abolhosseini S., Heshmati A. (2014), The main support mechanisms to finance renewable energy development, „Renewable and Sustainable Energy Reviews”, vol. 40, p. 876-885.

Akčný plán využívania biomasy na roky 2008-2013 (2008), p. 21. Available at: www.abe.sk/dokumenty/Akcny_plan.pdf. Accessed 25.09.2012.

Bergman A., Colombo S., Hanley N. (2008), Rural versus urban preferences for renewable energy developments, "Ecological Economics", vol. 65, p. 616-625.

Bolcárová P., Kološta S. (2015), Assessment of sustainable development in the EU 27 using aggregated SD index, "Ecological Indicators", vol. 48, p. 699-705. 
Crevoisier O., Maillat D. (1991), Milieu, industrial organization and territorial production system: towards a new theory of spatial development, [in:] R. Camagni (ed.), Innovation networks: Spatial perspectives, $p$. 13-34.

de Arce R., Mahia R., Medina E., Escribano G. (2012), A simulation of the economic impact of renewable energy development in Morocco, "Energy Policy", vol. 46, p. 335-345.

Domac J., Richards K., Risovic S. (2005), Socio-economic drivers in implementing bioenergy projects, "Biomass \& Bioenergy", vol. 28, no. 2, p. 97-106.

Elbersten B., Startisky I., Hengeveld G., Schelhaas M.-J., Naeff H., Böttcher H. (2012), Atlas of EU biomass potentials, Biomass Futures, Brussels.

Flaška F., Kološta S. (2011), Bioenergia ako inovativny element v regionálnom rozvoji, Banská Bystrica: Európa 2020 - stratégia pre inteligentnú, udržatel’nú a inkluzívnu Európu, p. 7-13.

Grotz R., Braun B. (1993), Networks, milieu and industrial firm strategies: empirical evidence of an innovative SME environment, "Geograficska Annaler", vol. 75B, no. 3, p. 149-162.

http://epp.eurostat.ec.europa.eu/portal/page/portal/energy/data/main_tables. Accessed 10.06.2013.

http://www.atlasoze.sk/biomasa.html. Accessed 2.05.2103.

http://www.priateliazeme.sk/cepa/eportal/index.php?option=com_content\&view=article\&id=31\&Itemid=77. Accessed 7.05.2013.

http://www.siea.sk/granty-dotacie-aktuality/c-1255/domacnosti-doposial-poziadali-o-75-prostriedkov-vyclenenych-na-dotacie/. Accessed 3.05.2013.

IEA (2007), Bioenergy Project Development and Biomass Supply, International Energy Agency, France.

Kautto N., Peck P. (2012), Regional biomass planning - Helping to realise national renewable energy goals?, "Renewable Energy", vol. 46, no. 46, p. 23-30.

Linkvist K.B. (1999), Governance, territoriality and local production systems in Norwegian fisheries, Workshop on "Management institutions and governance systems in European Fisheries", p. 28-30.

Liu W., Wang C., Mol A.P.J. (2013), Rural public acceptance of renewable energy deployment: The case of Shandong in China, "Applied Energy", vol. 102, p. 1187-1196.

Lunnan A. (2003), Contribution from bioenergy to local economic development - a Norwegian case study, Workshop on "Socio-Economic Drivers in Implementing Bioenergy Projects: Education and Promotion", p. 10-18.

Maga J., Nozdrovický L., Pepich Š., Marhavý L., Hajdu Š. (2008), Komplexný model využitia biomasy na energetické účely, Nitra.

Martinot E. (2012), Renewables 2012 Global Status Report, REN21 Renewable Energy Policy Network/Worldwatch Institute, p. 216.

Michalena E., Hills J.M. (2012), Renewable energy issues and implementation of European energy policy: The missing generation?, "Energy Policy", vol. 45, p. 201-216.

Ming Q., Guo S., Jiao Y. (2011), High Gradient Effects of Forest Biomass Energy in Mountainous Region. A Case of Meili Snow Mountain, "Procedia Earth and Planetary Science", no. 3, p. $315-320$.

Monitoring reports of Bioenergia Bystricko for years 2012 and 2013.

Murtinger K., Beranovský J. (2006), Energie z biomasy, Brno.

Pels J.R., De Nie D.S., Kiel J.H.A. (2005), Utilization of ashes from biomass combustion and gasification, European Biomass Conference Paris, France.

Plieninger T., Thiel A., Bens O., Hüttl R.F. (2008), Bioenergy Clusters in Austria and Germany: From Public Goals to Private, London.

Resch G., Panzer C., Busch S. (2010), Výhl'adová analýza využivania obnovitel’ných zdrojov energie na Slovensku, Viedeň. 
Ruhl C. (2008), BP Statistical review of world energy, Available at: http://www.bp.com/statisticalreview. Accessed 1.12.2009.

Sims R. (2002), The Brilliance of Bioenergy - in business and in practice, London.

Smernica Európske spoločenstvo no. 2009/28/ES o podpore využivania energie z obnovitelných zdrojov energie.

Švihlová D. (2009), Klimatické zmeny ako miestny problém: lokalizácia a implementácia na príklade Kanady, "Ekonomický časopis", vol. 57, no. 9, p. 918-932.

Švihlová D., Kožiak R., Král’ P., Slobodníková O. (2011), Environmentálna politika a regionálne disparity, Banská Bystrica.

Terrapon-Pfaff J. et al. (2014), A cross-sectional review: Impacts and sustainability of small-scale renewable energy projects in developing countries, "Renewable and Sustainable Energy Reviews", vol. 40, p. 1-10.

Zentková I., Cvengošová E. (2010), Využitie alternativnych zdrojov energie na Slovensku, "Rozvoj vidieka a štrukturálne zmeny v podnikatel'ských subjektoch v agrokomplexe”, p. 279-284. 